\title{
From the Inferior Other to the Becoming Being: a Reading of Dracula from Haddon's Frame
}

\author{
Rajni Singh \& Reema Chakrabarti \\ Associate Professor, Department of Humanities and Social Sciences, IIT (ISM), Dhanbad. \\ Orcid: oooo-0oo2-1569-8339. Email: rajnisingh18@gmail.com \\ Junior Research Fellow, Department of Humanities and Social Sciences, IIT (ISM), \\ Dhanbad.Email: chakrabarti.reemazo12@gmail.com
}

Received July 04, 2017; Revised November 20, 2017; Accepted November 30, 2017; Published December o9, 2017.

\begin{abstract}
The paper aims to analyze the vampiric figure Dracula as portrayed in the television series by Cole Haddon to understand the nature of identity and the socio-political constructions and constrictions that constitute the self. An individual's characteristics are often typecast by the projection of a 'singular affiliation view'. Through the character of Dracula, an attempt will be made to demonstrate how 'singular affiliation view' can be deconstructed through 'alternative identification'. In the process, it will also examine the agencies, such as knowledge, power, and relations that make Dracula a functioning individual who lives with the ambition to empower the self.
\end{abstract}

Keywords: Dracula; Alternate Identity; Knowledge/Power; Inter-relationships; Becoming Being.

\section{Introduction}

Identity is one of the most nuanced constructions of the socio-political formation as it is indeterminate and retracts over the alternating historical contexts. However, in certain specific instances, identities are often marred by the process of "reductionism" (Sen 20) that denies an individual's subjectivity over the choice of affiliation. In those occurrences, one is reduced to the state of an 'Inferior Other' as he/she is disregarded of the capacity to attune to multiple forums in "disparate contexts" (Sen 23). Refusal to acknowledge the multi-dimensional attributes of an individual narrows down the outlook towards him/her and leads to typecasting of a personality. Such "singular affiliation view" (Sen 25) confirms to the fractured logic of the dominant structure that prefers to restrict the identity of an individual to retain its superiority. However, in an alternative socio-political scenario, it challenges one at the epistemological level and subsequently creates a space to probe into certain possibilities that provide scope for a renewed comprehension.

Bram Stoker's idiosyncratic depiction of the character, Dracula as a marginalia and Haddon's projection of Dracula in Subject position raises questions about identity and alterity and the connection between the two, and also compels one to contemplate whether identity could be altered and what necessitates this act. These questions could be examined from the vantage point of Haddon's shift from the typecast image of the monster to a cultivated, well-bred

(c) AesthetixMS 2016. This Open Access article is published under a Creative Commons Attribution Non-Commercial 4.0 International License (http://creativecommons.org/licenses/by-nc/4.o/), which permits non-commercial re-use, distribution, and reproduction in any medium, provided the original work is properly cited. For citation use the DOI. For commercial re-use, please contact editor@rupkatha.com. 
man with cosmopolitan character. While dealing with Dracula, Haddon opts for an "alternative identification" (Sen 30) so that he is presented in a new frame which could offer him a renewed identity. However, this new-found identity is structured on multiple affiliations that are based on his background, associations, knowledge of past and present, and his social engagements.

\section{“Alternative Identification” of Dracula: Cole Haddon's Project}

Haddon's project of providing an "alternative identification" to the already established inferior status of Dracula is a purely American agenda owing to the fact that the idea of alternate history is primarily an American phenomenon'. Alternate history also called as 'allohistories 'ii or 'what if narratives ${ }^{\text {iii }}$ demands some change in the fundamental facts about history. It challenges the notion of identity as objective and stable ${ }^{\text {iv }}$.

In Haddon, Dracula's identity is based on alternate history. Except the setting of the story, which is in the $19^{\text {th }}$ century Victorian England, Haddon chooses to mystify the past to focus on the present. His past, if not fully obliterated, remains shrouded till it is unraveled by Van Helsing, who assertively addresses him as "Vlad Tepes", "The prince of Wallachia" (03:09- 03:17 Pilot 2). This provides a sufficient ground to relate him to the Romanian historical figure $\mathrm{v}$. But his provincial identity is presented within limits or rather marginalized in the series as he is shown as urbane, worldly and sophisticated young man empowered with scientific truth and is an entrepreneur in temperament. By attributing Dracula with these traits, Haddon changes the historical facts about the character. Thus in order to provide agency to Dracula, Haddon alters his position and endows him with heroic qualities. Simultaneously he reinstates the 'Order of the Dragon', but only symbolically, by projecting a building with the name "Empire and Colonial: METALLURGY" so as to build up the binary of light vs. dark, good vs. evil and to show that how they are in opposition to each other. Dracula's resistance to his past is delineated through his fight against the 'Order of the Dragon' that stands as an Imperialist power in its nature and design. ${ }^{\text {vi }}$ Interestingly, the trope of Imperialism is strategically used by Cole Haddon for it evokes one's inquisition towards the presumed notions of ethics and reality that are regulated by the dominant structure and its traces lie subverted in the gothic texts (Beville 2009:15).

Besides, historicizing the context, the Gothicism of the text also provides eternity to the character's identification that manifests in his functioning as a "differend" (Beville 2009:15). This phenomenon provides him the ability to escape one's judgment of "imposed realities and identities" (Beville 2009: 15), and thus, in an epistemological framework his identification leads to an interrogation of these aspects. Moreover as a "differend", Dracula evokes the simultaneous effects of fear and delight, which further draws one's attention to the historical Vlad Tepes who is patronized and at the same time apprehended for his cruelties ${ }^{\mathrm{vii}}$.

\section{Knowledge/Power and Dracula's Renewed Identity}

Power and knowledge stand synonymous to each other. Despite being distinct, the two are inextricably woven and exert influence on each other. In History of Sexuality Foucault postulates that knowledge constitutes itself as one of those heterogeneous elements that can be strategically implemented to generate dimensions of power (Foucault 1978:93). He argues that power/knowledge is productive as well as restraining. It not only limits one's action, but also opens up new ways of acting and thinking about oneself. In Haddon, Dracula's power is embodied in his discourse on scientific understanding. His declaration to bring geo-magnetic technology to 
the world, in the very first episode of the series, signifies necessary, productive and positive force that he wishes to bring in the society. He brings in geo-magnetic technology that becomes a source of "free, safe" and "wireless power" and makes light and energy easily accessible to the mass (12:27 Pilot 1). The execution of his technical knowledge promotes the supremacy of his endeavour as it is ahead of its time and has the potential to revolutionize the existing system and destabilize the power structure that implements and regulates it ${ }^{\text {viii }}$. Moreover, Dracula's conceptualization of a new source of energy reveals his socio-political knowledge about the dominant structure that functions its supremacy by its occupancy of the energy industry. The "historical content" of his past experiences becomes a profound source of "subjugated" knowledge (Foucault 81-82) that he evokes to yield a new source of awareness regarding the oppressive dimensions of the system and means ${ }^{\text {ix }}$ to overcome it. The source of technical knowledge also benefits his sense of identity because despite being a monster, he doesn't have to rely on the dark forces $^{\mathrm{x}}$ to establish his power rather he gains the ability to control the environment with the use of illuminating sources. He himself reflects upon the idea when he says, "I hope the experience (lighting of the bulbs) has been illuminating for you all" (17:34 Pilot 1).

Besides his technical knowhow, the glamour of his appearance charms his guests who feel captivated by the enticing appeal in the cosmopolitan rhetoric and are subsequently drawn towards his proposition. By doing so, Haddon elaborates the motif of a contemporary man who features "cosmopolitanism" and exploits it as "marketing strategy" (Spencer 2011: 23). If Dracula's obsession with his present project forces him to be in time and to be the sophisticated man, his knowledge of past haunts him time and again. He is well aware of the truth that behind the mask of a cultured, cultivated cosmopolitan, he is a monster. The monstrousness eternalizes his being that provides opportunity for the manipulation of identity since people do not have any concrete knowledge of his existence. Thus, he disguises as an American among the people of Victorian England in whom, he wants to instigate a sense of cosmopolitanism that would fetch him greater acceptability of his endeavour. According to Spencer, the phenomenon of cosmopolitanism can be created if one sensitively penetrates into "the world beyond one's immediate milieu" (Spencer 4). Posing as an American, Dracula creates an appeal for the foreign element. On top of that, he convinces people that he is sensitive toward the Victorian world and displays humility while welcoming them- "Welcome to my house, may you enter freely, go safe and please... leave some of the happiness that you bring along" (14:37 Pilot 1). The aura of cosmopolitanism also encompasses "an enlarged sense of moral and political responsibility to individuals and groups outside one's local or national community" (Spencer 4). To propagate the notion of genuine concern for people, Dracula emphasizes on "darkness" (11: 46 Pilot 1) and makes them believe that how it haunts the society because of its dominating and oppressive political structures and convinces them that the success of his new project is likely to destroy the existing structure that controls the energy industry through the means of elementary technology. Thus, Dracula's project provides a hope for the people to come out of the oppressive moulds that they were into for ages.

According to Foucault, knowledge constitutes as one of the heterogeneous sources that together align or at times conflict to stabilize or destabilize the sources of power (Rouse 14). To strengthen one's position in the society, it is required to resist the authority and evade its effect by participating in the vivid "counter-alignments" that would weaken the existing superior forces (Rouse 15). Resultantly, Dracula fetches a realistic proposition that he strategically implements by illustrating a demonstration of its functioning. While the crowd applauds Dracula for the light that he brings to the world (19:37 Pilot 1), the members from the authoritative organization feel shocked and shaken by his achievement as they are directly challenged by the realism of his enterprise. Witnessing the fear in their eyes, Dracula exhilarates at the thought of having 
established his supremacy over the dominant structures. His robust laughter and loud proclamation "the future belongs to me" (20:35 Pilot 1) depicts a sense of authoritativeness which he has gained through knowledge. Making appropriate use of his epistemological sources, he destabilizes the power structure which is maintained through oppressive measures and can be dismantled only with the effective use of the multiple resources ${ }^{\mathrm{xi}}$ that heterogeneously constitute to its alignment (Rouse 14).

\section{The Self as a Mutually Constitutive Identity}

To constitute one's identity, it becomes significant to build/manage relationships since the 'self' can attain its completeness only after it inter-relates with the different organs of the society. This idea corresponds to the fact that the psychological mechanism that constitutes the self has the tendency to locate itself in relation to others (Benson 3). Consequently, the totality of one's identity is formed by an accumulation of all 'inter-relationships' that together constitutes the self (Garcia 103). In the series, Dracula particularly associates himself with characters like Renfield, Mina Murray, Prof. Van Helsing and Lady Jane Wetherby. The course of their actions and interaction incorporates essential element to the narrative structure and also provides an expanse for a clarified understanding of his personality.

Renfield tends to be one of the closest associates of Dracula who also plays the role of "camaraderie" (Haddon interview to Essman \& Irabor) for Dracula confides every details of his mission to Renfield. Both of them share a position beyond the hierarchically stratified society in which they have often faced the problems of emptiness and desertion-

$$
\begin{aligned}
& \text { Renfield: I was imprisoned for the crime of defending myself (40:28 Pilot 5) } \\
& \text { Renfield: I was left friendless and penniless (40:40 Pilot 5) } \\
& \text { Dracula: I too know how it is like to live as an outcaste (41:19 Pilot 5) }
\end{aligned}
$$

Their bitter experience of the past that emanates from the societal structures and strictures brings them closer. They collaborate to alter the course of their "autoethnographic" narration by functioning as "abolitionist intellectuals" (Pratt 2012: 29) to dismantle the exploitative structure. Thus, Renfield assists Dracula in implementing his "significant project(s)" (Pratt 2012: 25) that can establish his control and supremacy in the societal domain. The union of Renfield and Dracula is confirmed by an essentialist notion of identity that stabilizes relationships by the unanimity of experience and confirms loyalty during difficult expeditions. In his journey to establish his alphahood, Dracula's companionship to Renfield creates brotherly ties among them and thus helps him to mitigate the trauma that has been caused by the inability to execute ordinary relationships and activities that are enjoyed by majority of the society (Levitas 2007: 9).

Dracula's personality and knowledge magnetizes the female characters as well. At the first site itself, Mina Murray is spell-bound by Dracula's personality and does not hesitate in building romantic affiliations with him. In due course of time, they harbor mutual affection for each other. This sense of mutuality with Mina Murray deconstructs Dracula's identity as a solitary figure and brings him to a new position where he experiences a sense of belongingness and admires the beauty of relationship- "I belong to you and you belong to me" (41:09 Pilot 8). But, the historical knowledge of his social positioning threatens him from establishing a relationship with Mina Murray who represents the Victorian aristocratic stratum. However, the dilemma that he lives in 
makes him even stronger. His constant evaluation and assessment of his relationship with Mina Murray teaches him to bring a balance between the private and public selves. Consequently, every aspect of their association is guided by the approaches of "formality" that creates a shield for any form of "intimacy" (Bologh 1990: 217) and thus their gestures are guided by the norms of good "social encounter" in which one seeks happiness in the pleasure of others (Bologh 1990: 217). Dracula's intense affection for Miss Mina Murray is reflected in his encouraging notes to her to follow her dreams. Being a Victorian woman, Miss Murray faces the challenges of the society that has oppressive policies for the weaker sex and she often faces criticism for her dreams to pursue a career in medical science, "I am going to be a doctor... and that was all very sweet and charming until I was fourteen or so" (29:09 Pilot 2). The strictures of the society often lead to the positioning of ambivalence in her intellectual capacity and resultantly, she starts apprehending the possibility of an epistemic failure. However, Dracula emerges as a rational being who retorts such typecast, "When it comes to dreams... one may falter, but the only way to fail is to abandon" (30:48 Pilot 2). The cosmopolitan aura that surrounds his personality creates an "intellectual praxis" within the signification of his experience (Hau 134) - resulting to the formation of reliability in his personality by which Mina Murray gains confidence in her project. Despite, such aura, Dracula displays vulnerability upon being interrogated of his feelings for her and thus prevents the discussion from proceeding- "Don't ask me that" (39:37 Pilot9). Though these encounters are meant to be limited within the dimensions of "sociability" (Bologh 1990: 217), yet at the end, a union with Mina Murray becomes the only source of happiness for Dracula as she enriches his senses and affects his life internally (Bologh 1990: 217).

While some relations bring comfort to Dracula, others turn out to be difficult, but it is interesting to note that Dracula manages those relationships as well. He feels directly challenged by Prof Van Helsing's colonialist designs that targets to cast Dracula as a neo-colonial 'another' (During 2012: 60). Though Dracula continues to manage the relationship pragmatically, yet he does not fail to recognize Helsing as a "non-filiative" (During 2012: 61) agency of the dominant structure that implements cruel strategies to hurt others- "It is not the blood you draw that bothers me Van Helsing, but the sublime pleasure you derive out of my pain" (29:35 Pilot 1). The contrast of motive between the two characters glorifies the personality of Dracula who aims to bring justice to people by revolutionizing the existing system unlike Van Helsing who only aims for revenge. Though they both attempt to overthrow the dominant class; yet their union remains superficial as Dracula continues to resist the depravity of Van Helsing and upholds the moral norms $^{\text {xii }}$. Also, Dracula feels challenged by Lady Jane Wetherby whose functions as a vampirehunter threatens his own existence. Dracula initiates a relationship with her for the sole purpose to dissuade her from the knowledge of his reality. He is prompt at recognizing Jane Wetherby's fascination for his charms. And so, he begins an intense affair with her with the intention to gratify her sexual urges.

In order to fulfill his ambitions, Dracula also uses his knowledge to instigate certain murders and homicide of people who stand as a barrier to his ambition. In the series, Dracula kills people like Cougar and one of the lords from the dominant organization. However, even before killing them, he strongly asserts his identity and intentions. The revelation of his real identity sets a discourse for counter-identification that Dracula generates in the process of his struggle.

Thus, knowledge stands vital in determining one's position in society. Knowledge also plays a significant role in determining the pragmatics of working relationships that align together to determine one of the most important constitution of the self. Dracula's associations with 
people, his scientific temperament, his inter-personal relations and his personality traits contribute significantly in establishing him as a powerful figure.

\section{Conclusion}

The establishment of the 'self is an ongoing process that continuously refers to the multiple affiliations like the knowledge/power institutions, relationships, and the domains of struggle for its complete constitution and understanding. However, at times, these agencies tend to attest the self with certain categorization and typecast that do not attune with the individual's interest. In Bram Stoker, Dracula mostly remains stereotyped as a monster whose characteristics are revealed only through partial reference by the agencies who conceive him. As a muted figure, his scope at influencing the surrounding remains passive and the typecasting of his monstrosity perhaps does not attune to his interest. It would not be wrong to assert that the society utilizes Dracula's positioning as a marginalia and fabricates an identity for him in accordance to its own convenience. This amounts to 'reductionism' (Sen 20) in the process of individual's identity construction. However, in an alternative socio-political scenario, such redundant construction provokes the thoughtful population and also necessitates a recreation of the 'self by identifying the existing lapse and further possibilities. Exploiting the gaps of Stoker's inference, Haddon explores the possibilities for a further interpretation into the individual's characterization. Thus, he brings Dracula to the center stage from where he can his exert influence on different situations and people by the effective use of knowledge and manipulation. Doing so, his identity does not remain restricted to a particular frame and he emerges as a functioning individual who is in the process of locating and empowering the self. Dracula's survival in the concluding episode of the series further validates the idea that how alternative identification proves rewarding for this monstrous figure as his 'single-affiliation view' is altered; from the historical inferior other he is altered to a becoming being.

\section{Notes}

${ }^{\text {i }}$ American literature mostly fall under the category of "multiethnic" literature that contributes a lot to the debates of "community, justice and freedom" (Garcia 102)

ii "Alternate history" is often used as a phenomenon in "pop literature" that pervades the horizon of books, films and television. Within the purview of these categories, one adheres to "counter-factual thinking" to postulate "alternative outcome to past events" (Singles 2).

iii "What if" narratives are an outcome of such allohistorical text that influence the readers' cognition of alternative possibilities for a particular premise (Singles 2).

iv The massive destruction of the two world wars undermined the honoured identities of pre-War Europe which gave rise to the notion that identity is neither objective nor stable.

"Vlad Tepes has been an "archetypal leader" (Nicol 2002: 45) whose glory continues to pervade the Romanian sentiment and intensify their feeling of nationalism for he stands as a charismatic figure that fought for the justice of the people within his domain

${ }^{\mathrm{vi}}$ Haddon clarifies this idea by projecting a building by the name "Empire and Colonial: METALLURGY" (07:53 Pilot 3). 


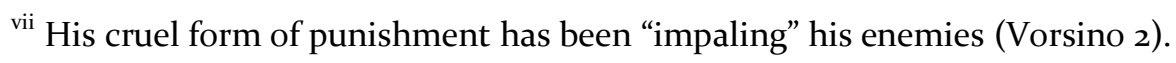

viii The present source of power.

ix The technological revolution becomes a source of emancipation for him as well as the mass who can free themselves from being subjugated by the Order.

${ }^{x}$ Dark forces for a monster imply negative strength and savagery.

${ }^{x i}$ Of the multiple resources, knowledge is one such resource.

${ }^{\text {xii }}$ He upholds the virtues of love, faith and friendship, even in face of crisis.

\section{References}

"A Whiff of Sulfur". Dracula. Prod. Daniel Knauf, Dir. Steve Shill, Wr. Daniel Knauf. NBC: US. 1 Nov 2013.

Beville, Maria (2009). Gothic-postmodernism: Voicing the Terrors of Postmodernity. Rodopi: Amsterdam.

Bologh, Roslyn Wallach (1990). Love or Greatness: Max Weber and Masculine Thinking- A Feminist Inquiry. Routledge Revivals: London.

During, Simon (2012). "Rousseau's patrimony: primitivism, romance and becoming other". Colonial Discourse/ Postcolonial Theory. Eds. Francis Barker, Peter Hulme and Margaret Iversen, eds. 47-71, Viva Books: New Delhi, Mumbai, Chennai.

Essman, Scott, \&Osahon Irabor (2014). "Cole Haddon: A Screenwriter Reinvents Dracula”. Below the Line: Voice of the Crew. 11 Aug Web 20 Sep 2016. Doi: www.btlnews.com/news/cole-haddon-a-screenwriterreinvents-dracula/

Foucault, Michel (1972). Power/Knowledge: Selected Interviews and Other Writings (1972-1977). Ed. Colin Gordon. Trs. Colin Gordon, Leo Marshall, John Mepham, Kate Soper (78-108). Pantheon Books: New York.

Foucault, Michel (1978). History of Sexuality Vol I: An Introduction. Trans. Robert Hurley. Pantheon Books: New York.

"Four Roses". Dracula. Prod. Daniel Knauf, Dir. Tim Fywell, Wr. Jesse Peyronel, Teleplay. Daniel Knauf. NBC: US. 17 Jan 2014.

"From Darkness to Light." Dracula. Prod. Daniel Knauf, Dir. Andy Goddard, Wr. Tom Grieves. NBC: US. 15 Nov 2013.

"Goblin Merchant Men”. Dracula. Prod. Daniel Knauf, Dir. Andy Goddard, Wr. Tom Grieves. NBC: US. 8 Nov 2013.

Hames- Garcia, Michael R, (2001). "Who Are Our Own People?: Challenges for a Theory of Social Identity", pp. 102-127. Reclaiming Identity: Realist Theory and the Predicament of Postmodern, eds. Paula M.L. Moya \& Michael R. Hames-Garcia. Orient Blackswan: Hyderabad.

Hau, Caroline S., (2001). "On Representing Others: Intellectuals, Pedagogy, and the Uses of Error", pp. 133165. Reclaiming Identity: Realist Theory and the Predicament of Postmodern, eds. Paula M.L. Moya \& Michael R. Hames-Garcia. Orient Blackswan: Hyderabad.

Hearn, Jonathan (2012). Theorizing Power. Palgrave Macmillan: US.

"Let There Be Light". Dracula. Prod. Daniel Knauf, Dir. Tim Fywell, Wr. Cole Haddon. NBC: US. 24 Jan 2014.

Levitas, Ruth, Christina Pantazis, EldinFahmy, David Gordon, Eva Lloyd, \& Demi Patsios (2007). The MultiDimensional Analysis of Social Exclusion. "Department of Sociology and School for Social Policy Townsend Centre for the International Study of Poverty and Bristol Institute of Public Affairs". 
University of Bristol. Web 15 Oct 2016. Doi:

www.bristol.ac.uk/poverty/downloads/socialexclusion/multidimensional.pdf

Nicol, D. A. (2002). The horrific hero: The image of vlad țepeș (the impaler) dracula. A medieval prince and romanian nationalism in the 20 th century (Order No. 140890o). Available from ProQuest Dissertations \& Theses Global. (230785082). Retrieved from https://search.proquest.com/docview/230785082?accountid=49706

Pratt, Mary Louise (2012). "Transculturation and autoethnography: Peru 1615/1980”. Colonial Discourse/ Postcolonial Theory. Eds. Francis Barker, Peter Hulme and Margaret Iversen, eds. 24-46, Viva Books: New Delhi, Mumbai, Chennai.

Rouse, Joseph (2005). "Power/Knowledge”. Division I Faculty Publications. Paper 34.

Sen, Amartya (2006). Identity E Violence: The Illusion of Destiny. Penguin Books: London.

Spooner, Catherine (2006). Contemporary Gothic. Reaktion Books: London.

Spencer, Robert (2011). Cosmopolitan Criticism and Postcolonial Literature. Palgrave Macmillan: UK, US.

Stoker, Bram (1897). Dracula. Web i Sep 2016. Doi: www.planetebook.com>ebooks $>$ Dracula

“The Blood is the Life”. Dracula. Prod. Daniel Knauf, Dir. Steve Shill, Wr. Cole Haddon. NBC: US. 25 Oct 2013.

“The Devil's Waltz”. Dracula. Prod. Daniel Knauf, Dir. Nick Murphy, Wr. Nicole Taylor. NBC: US. 17 Jan 2014.

Topel, Fred (2013). “Exclusive Interview: Cole Haddon on 'Dracula'.” Crave. 25 Oct. Web 22 Sep 2016 doi: www.craveonline.com/site/593907-exclusive-interview-cole-haddon-on-

dracula?utm_source=rss\&utm_medium=rss\&utm_campaign=exclusive-interview-cole-haddon-ondracula

Weber, Max (1949). On The Methodology of the Social Sciences. Trans. Edward A. Shils, Henry A. Finch. The Free Press of Glencoe: Illinois.

Williams, Raymond (2003). Television: Technology and Cultural Form. Ed. Ederyn Williams. Routledge: London \& New York.

Vorsino, M. (2007). Dracula: From historical voievod to fictional vampire prince (Order No. 1455363). Available from ProQuest Dissertations \& Theses Global. (304708313). Retrieved from https://search.proquest.com/docview/304708313?accountid=49706 